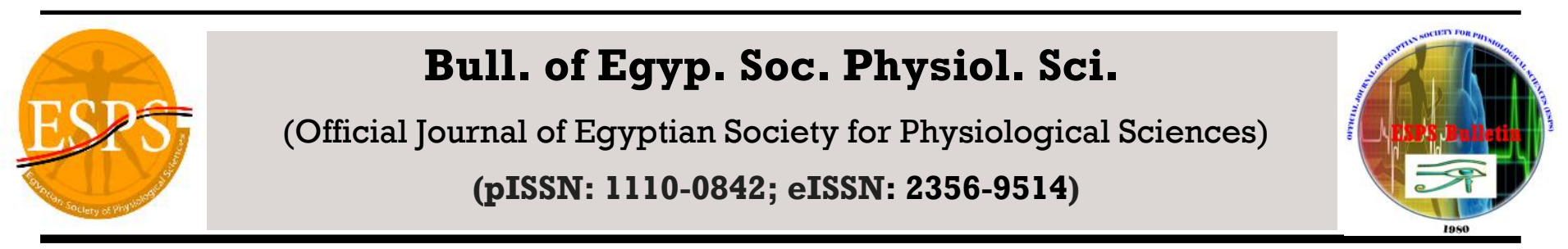

\title{
Role of Melatonin in Arterial Blood Pressure Modulations and Renal Damage Induced By Ethanol Consumption in Adult Male Rats
}

\author{
Ebtihal A. Abd El-Aziz \\ Department of Physiology. Faculty of Medicine. Assiut University. Egypt.
}

Received: 3 Feb 2015

Accepted: 25 April 2015

Available online: 1 May 2015

\section{Keywords}

- Ethanol

- Melatonin

- $\mathrm{ABP}$

- $\mathrm{TNF}-\alpha$

- VEGF

- Renal caspase3activity.

\section{Abstract}

Background and objectives: Ethanol exposure produces hypertension and many changes in the kidney. Melatonin has potent antioxidant and anti-inflammatory properties. The aim of this study is to detect the role of melatonin on arterial blood pressure (ABP) and its probable protective effects against renal dysfunction induced by ethanol in adult male rats. In addition, the possible involved mechanisms of melatonin using biochemical and histopathological methods were evaluated. Methods: Forty eight rats divided into three groups; control, ethanol treated and melatonin + ethanol treated groups. Half of the animals were sacrificed after six weeks (6Ws) and the other after twelve weeks (12Ws) for each group. Ethanol treated group: the animals of this group received $10 \mathrm{ml} / \mathrm{kg}$ of BW $30 \%$ ethanol by intra-gastric tube at alternate days. Melatonin+ ethanol treated group: the animals of this group received the pervious ethanol dose and $5 \mathrm{mg} / \mathrm{kg}$ melatonin injected subcutaneously at alternate days. Results: In ethanol treated group after the $6^{\text {th }}$ and $12^{\text {th }}$ week, there were significant decreased body weight (BW), significant increased (ABP) and tumor necrosis factor alpha (TNF- $\alpha$ ). However, after the $6^{\text {th }} \mathrm{W}$ serum urea, creatinine, vascular endothelial growth factor (VEGF) and renal caspase-3 activity were not significantly changed, but these parameters were significantly increased except VEGF which significantly decreased at (12Ws). In ethanol treated group for 6Ws and 12Ws dilatation, congestion of the peritubular vessels and dilated bowman's spaces were obvious. Dilated tubules lined by thinner epithelium with degenerated cells at some areas were also noticed. Degeneration and necrosis of renal tubular epithelia were more obvious following twelve weeks ethanol treatment. These damaging changes reflected toxic effects of ethanol with the duration of exposure. These parameters and histopathological effects were ameliorated by the melatonin. Conclusion: Melatonin has a protective role in elevated (ABP) and renal damage induced by ethanol.

Corresponding author: Ebtihal A. Abd El-Aziz, Department of Medical Physiology, Departments of Physiology, Assuit Faculty of Medicine, Assuit, Egypt. phone: +2001004270932; email: ebthal2@gmail.com 


\section{INTRODUCTION}

In chronic alcoholic condition not only kidney but liver was also affected (1). While acute alcohol consumption has a nephrotoxic effect on the kidney, alternatively, chronic use in humans may result in alcohol-induced hypertension, indirectly increasing the risk of chronic kidney disease $(2,3)$. TNF- $\alpha$ is a primary cytokine that initiates the inflammatory cascades by inducing secondary cytokines and key enzymes. It has been shown to play an important role in apoptosis (4). Ethanol administration stimulates an increased Kupffer cells $(\mathrm{KCs})$ mediated production and release of TNF- $\alpha$ and IL- 6 , cytokines that have been associated with inflammatory responses and hepatocellular damage in chronic disease states(5). Deterioration of renal function may be one of the most important factors associated with a significant increase in TNF- $\alpha$ activity (6). Ethanol intoxication in obese mice increases TNF- $\alpha$ which activate hepatic caspase-3(4).

Ethanol consumption can lead to cell apoptosis in various tissues such as liver (7), heart (8), stomach (9) and brain (10), which has been confirmed in rats, mouse and human experiments. Apoptosis is a complex process involving a variety of different signaling pathways and results in a multiple of changes in the dying cell (11). Most of the members of the caspase family are expressed in the kidney. Caspases-3 and -6 are localized predominantly in renal tubular epithelium (12).

Growth factors are signaling molecules playing crucial roles in the response to ethanol intoxication influencing the survival, differentiation, maintenance, and connectivity of cells of the brain, kidney, and liver (13). VEGF is one of the major growth factor regulating the pathophysiology of kidney (14). VEGF receptors can also be expressed in tubular epithelial cells, and the enhanced expression might provide survival benefit in situations such as renal ischemia and toxic injury (15). In addition, recent evidence indicates that VEGF plays an important role in endothelial cell proliferation and capillary repair in the glomeruli (16).

Melatonin activates various physiological functions causing sleep/wake rhythm, circadian rhythm, blood pressure control, immune system activity, detoxification of free radicals (17). It had been shown to improve apoptosis and cell injury in the liver of male rats (18). Melatonin acts upon the kidney through multiple pathways: as an antioxidant, as an apoptosis modulator, and as a circadian modulator of vascular function (19).

Most renal functions, including glomerular filtration rate, urine production, and solute excretion, exhibit circadian changes. There is an increase in the concentration of urine during the nocturnal period, which may be mediated by melatonin. Its receptors are predominantly localized in the proximal tubular segments (20). Melatonin has a protective effect on the structural alterations of proximal tubules of the kidney induced by gentamicin (21).

The aim of the present study is to evaluate the role of melatonin on blood pressure changes after exposure to ethanol, as well to detect its probable protective effects against cell death and tissue dysfunction in the renal injury induced by ethanol in adult male rats. Also, an attempt was undertaken to investigate the mechanisms responsible for these changes. 


\section{MATERIALS AND METHODS}

Experimental animals

A total number of forty eight adult male albino rats about (175- $200 \mathrm{~g})$ were purchased from animal house of Assiut University. The experimental protocol was approved by the Institutional Animal Research Committee of the Faculty of Medicine, Assiut University, Egypt. They were housed in an aerated room temperature $\left(25^{\circ} \mathrm{C}\right)$ and a light/dark (12 h:12 h) cycle, food and water were provided ad-libitum. The body weight was carried out at the start of the experiment, at six weeks and twelve weeks before animal decapitation.

Chemicals

Melatonin was obtained from (Sigma Chemical Co., St Louis, MO, USA).

\section{Experimental Design}

After one week of acclimatization, rats were randomly divided into the following groups each of which was 16 rats. Control group: the animals of this group received saline orally by intra-gastric tube. Eight rats were sacrificed after six weeks, and the other after twelve weeks. Ethanol treated group: the animals of this group received $10 \mathrm{ml} / \mathrm{kg}$ of body weight $30 \%$ ethanol by intra-gastric tube (22) at alternate days. Eight of them were sacrificed after six weeks, the other after twelve weeks. Melatonin+ ethanol treated group: the animals of this group received the pervious ethanol dose and $5 \mathrm{mg} / \mathrm{kg}$ melatonin injected subcutaneously (23) at alternate days. Melatonin was dissolved in absolute ethanol and then the solution diluted with saline. Eight of them were sacrificed after six week, the other after twelve weeks.
Blood pressure, systolic blood pressure (SBP) and diastolic blood pressure (DBP) were measured in unanesthetized rats, at six week and at the end of experiments, with a pneumatic tail pulse transducer (Narco physiograph, model DMP4A, Biosystems, Inc., Houston, TX). The animals had been pre warmed in a metal chamber at approximately $30{ }^{\circ} \mathrm{C}$ and allowed to rest and allowed to acclimatize for 20 minutes before the recordings were made. Three consecutive measurements were made at the same time of day. Mean systolic and diastolic blood pressure values from three measurements were recorded as the pressure value for each animal.

\section{Sample collection}

After the end of the experimental period, blood was collected in glass tubes from orbital sinus and whole blood was centrifuged after clotting, and the serum was separated and the samples were maintained at $-20{ }^{\circ} \mathrm{C}$ until used. Then the animals were sacrificed, kidneys were obtained. One of the kidneys was used for assessment of renal caspase- 3 activity and the other was fixed in $4 \%$ gluteraldehyde solution.

a- Estimation of biochemical parameters in the serum

Serum urea and creatinine levels were measured with a spectrophotometric technique using commercial kits (Olympus, Hamburg, Germany) (24 ) and presented as milligram per deciliter. Serum TNF- $\alpha$ level was determined using ELISA kit (Invitrogen, Carlsbad, CA, USA) (25) according to manufactures instructions. Serum VEGF level was determined using ELISA mouse/rat VEGF assay kits (Quantikine, R\&D

\section{Blood pressure measurement}


Systems, Minneapolis, MN, USA) (26 ) according to the manufacturer's instructions.

\section{$b$-The renal activity of caspase-3}

A specimen $(50 \mathrm{mg})$ was taken from each frozen kidney and homogenized with $20 \mathrm{mM} \mathrm{N-2-}$ hydroxyethylpiperazine- $N 8$-2- ethanesulfonic acid (HEPES, pH 7.5), containing 10\% sucrose, $0.1 \% 3$ [(3- cholamidopropyl)dimethylammonio]-1propanesulfonate (CHAPS), $2 \mathrm{mM}$ dithiothreitol (DTT), $0.1 \% \quad$ NP-40, $1 \mathrm{mM}$ EDTA, $1 \mathrm{mM}$ phenylmethylsulfonyl fluoride (PMSF), $1 \mu \mathrm{g} / \mathrm{ml}$ leupeptin, and $1 \mu \mathrm{g} / \mathrm{ml}$ pepstatin A. The supernatants obtained after centrifugation at 2,000 $g$ were used to determine enzyme activity by caspase-3 colorimetric assay kit (Assay Design, Inc. Michigan USA) (27 ).The standard protocol was followed as detailed by the manufacturer. The caspase-3 activity was expressed as unit/mg tissue weight.

\section{Histopathological examination}

For light microscopic investigations, samples from the kidney were taken from all groups after scarification then fixed in $4 \%$ gluteraldehyde solution. Semithin sections were cut at $0.5-1 \mu \mathrm{m}$ and were stained with Toluidine blue (28) and examined with light microscope.

\section{Statistical analysis}

Data were presented as means \pm standard deviation (SD). Differences between groups were determined by non parametric Mann Whitney test. The level of significance was accepted with $\mathrm{P}<0.05$. Prism computer program (graph pad version 3.0) was used for statistical analysis.

\section{RESULTS}

\section{1-Body weight}

Results clearly showed that the body weight of ethanol treated rats for six weeks and twelve weeks were significantly lowered $(\mathrm{P}<0.001$ for each) when compared with the control. Melatonin administration in the melatonin+ ethanol treated group associated with significant improvement of the body weight at six and twelve weeks when compared to the ethanol treated group and the response was manifested more at twelve weeks ( $\mathrm{P}<0.05$ and $\mathrm{P}<0.001$ respectively) but they were significantly lowered when compared to the corresponding control group $(\mathrm{P}<0.01$ for each). Table 1 shows results of 6 weeks and table 2 shows results of 12 weeks.

\section{2- Biochemical markers}

TNF- $\alpha$ level of the ethanol group at six and twelve weeks significantly increased $(\mathrm{P}<0.001$ for each) when compared with the control. Treatment with melatonin reduced significantly the level of TNF- $\alpha \quad(\mathrm{P}<0.001$ for each $)$ in melatonin+ ethanol treated group as compared to the ethanol treated groups. However, TNF- $\alpha$ level of the melatonin+ ethanol treated group for six and twelve weeks were significantly increased as compared to control groups $(\mathrm{P}<0.05$ and $\mathrm{P}<0.01$ respectively) (Table 1,2).

Estimation of serum level of VEGF in ethanol group at twelve weeks was significantly decreased as compared to the control group $(\mathrm{P}<$ 0.001). Treatment with melatonin for twelve weeks restored significantly its level $(\mathrm{P}<0.05)$ when compared to the ethanol treated group, but it was still significantly lower than control group $(\mathrm{P}<$ $0.01)$. No significant difference in the serum level of VEGF between the ethanol treated, melatonin+ 
ethanol treated and control groups at six weeks were detected (table 1 and 2).

Compared with the control group Caspase3 activity in renal homogenate was significantly increased in ethanol group at twelve weeks $(\mathrm{P}<$ 0.01). An administration of melatonin was associated with significant decrease in caspase-3 activity levels in the renal homogenate $(\mathrm{P}<0.05)$ as compared to the ethanol group. Comparing with control group, caspase-3 levels of the melatonin+ ethanol treated group at twelve weeks were significantly increased $(\mathrm{P}<0.01)$ (table 2). No significant difference in caspase-3 activity between the ethanol, melatonin+ ethanol treated group and control groups at six weeks (table 1).

Table (1): Mean \pm SD of body weight, serum levels of TNF- $\alpha$, VEGF, urea, creatinine, and caspase-3 in renal homogenate in different studied groups at six weeks.

\begin{tabular}{|c|c|c|c|}
\hline & $\begin{array}{c}\text { Control } \\
n=8\end{array}$ & $\begin{array}{c}\text { Eth }(6 \mathrm{~W}) \\
\mathrm{n}=8\end{array}$ & $\begin{array}{c}\text { Mel + Eth (6W) } \\
n=8\end{array}$ \\
\hline $\begin{array}{l}\text { BW } \\
(\mathrm{g})\end{array}$ & $178.50 \pm 5.10$ & $\underset{* * *}{165.10 \pm 5.20}$ & $\begin{array}{c}170.80 \pm 5.20 \\
* *, \#\end{array}$ \\
\hline $\begin{array}{l}\text { TNF- } \alpha \\
(\mathbf{p g} / \mathbf{m L})\end{array}$ & $3.38 \pm 0.90$ & $\begin{array}{c}14.50 \pm 0.90 \\
* * *\end{array}$ & $\begin{array}{c}4.90 \pm 1.10 \\
*, \# \# \#\end{array}$ \\
\hline $\begin{array}{c}\text { VEGF } \\
(\mathbf{n g} / \mathbf{m L})\end{array}$ & $56.25 \pm 4.20$ & $\begin{array}{c}52.50 \pm 3.20 \\
\mathrm{NS}\end{array}$ & $\begin{array}{c}54.38 \pm 2.20 \\
\text { NS, ns }\end{array}$ \\
\hline $\begin{array}{c}\text { caspase-3 } \\
\text { (U/mg tissue weight) }\end{array}$ & $4.00 \pm 0.8$ & $\begin{array}{c}4.75 \pm 0.70 \\
\mathrm{NS}\end{array}$ & $\begin{array}{c}4.25 \pm 0.70 \\
\mathrm{NS}, \mathrm{ns}\end{array}$ \\
\hline $\begin{array}{c}\text { Serum urea } \\
(\mathbf{m g} / \mathbf{d l})\end{array}$ & $14.13 \pm 1.60$ & $\begin{array}{c}15.38 \pm 2.10 \\
\mathrm{NS}\end{array}$ & $\begin{array}{l}14.75 \pm 1.90 \\
\mathrm{NS}, \mathrm{ns}\end{array}$ \\
\hline $\begin{array}{l}\text { Serum creatinine } \\
(\mathbf{m g} / \mathbf{d l})\end{array}$ & $0.47 \pm 0.06$ & $\begin{array}{c}0.51 \pm 0.03 \\
\mathrm{NS}\end{array}$ & $\begin{array}{c}0.49 \pm 0.02 \\
\mathrm{NS}, \mathrm{ns}\end{array}$ \\
\hline
\end{tabular}

$* \mathrm{P}<0.05, * * \mathrm{P}<0.01$, *** $\mathrm{P}<0.001$, NS: non significant as compared to control group. \# $\mathrm{P}<0.05$, \#\#\# $\mathrm{P}<0.001$ and ns: non significant as compared to Eth. group at six weeks. $\mathrm{BW}=$ body weight, Et= ethanol, Mel+ Eth= melatonin+ ethanol, VEGF= vascular endothelial growth factor

As shown in the table (2), serum urea and creatinine increased significantly in ethanol treated group at twelve weeks compared to the control $(\mathrm{P}<$ 0.001 for each). The reduction were obvious and significant with the melatonin treatment $(\mathrm{P}<$ 0.001 and $\mathrm{P}<0.01$ respectively) at twelve weeks when compared to ethanol treated group, but their levels were still significantly higher than the control groups ( $\mathrm{P}<0.05$ for each).

\section{Arterial blood pressure}

According to figure (1a\&b, 2a\&b) the animals treated with ethanol for six and twelve weeks displayed significant increased in both SBP and DBP when compared to both the control $(\mathrm{P}<0.01$ for SBP at $6 \mathrm{w}, \mathrm{P}<0.05$ for $\mathrm{DBP}$ at $6 \mathrm{w}$ and $\mathrm{P}<0.001$ for both SBP and DBP at $12 \mathrm{Ws}$ ). Melatonin supplementation ameliorated significantly both SBP and DBP when compared to both ethanol groups (at six weeks $\mathrm{P}<0.05$ for each, at twelve weeks $\mathrm{P}<0.001$ for $\mathrm{SBP}$ and $\mathrm{P}<0.01$ for DBP). In melatonin+ ethanol treated group for six and twelve weeks there were significant increase $(\mathrm{P}<0.05$ for all) when compared with the control. 

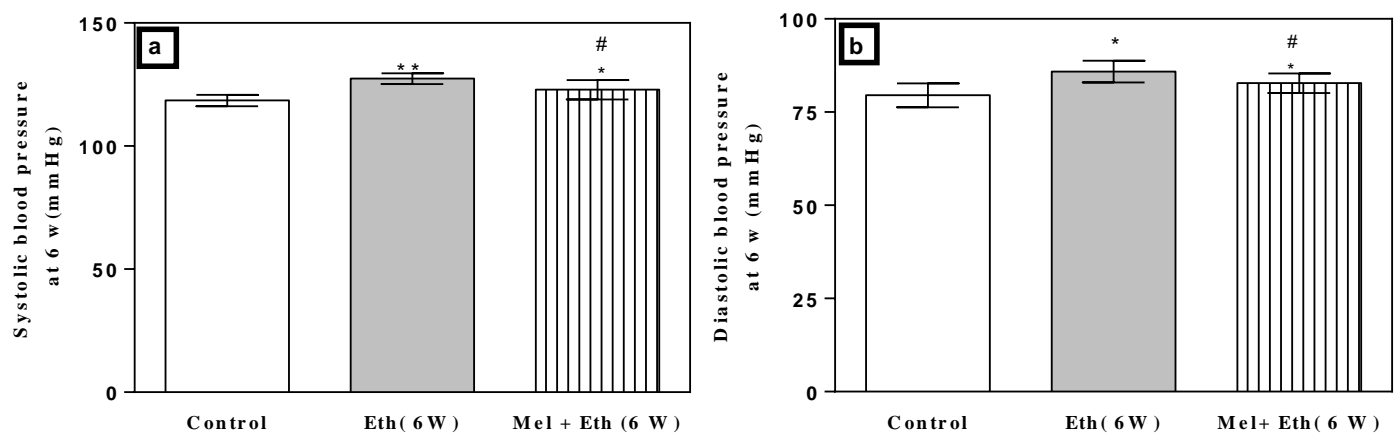

Figure (1), a: mean systolic blood pressure b: mean diastolic blood pressure in the studied groups at six weeks. *: $\mathrm{P}<0.05$ and **: $\mathrm{P}<0.01$ as compared to control group.\#: $\mathrm{P}<0.05$ as compared to Eth group.

Table (2): Mean \pm SD of body weight, serum levels of TNF- $\alpha$, VEGF, urea, creatinine, and caspase - 3 in renal homogenate in different studied groups at twelve weeks.

\begin{tabular}{|c|c|c|c|}
\hline & $\begin{array}{c}\text { Control } \\
\mathrm{n}=8\end{array}$ & $\begin{array}{c}\text { Eth }(12 W) \\
n=8\end{array}$ & $\begin{array}{c}\text { Mel+ Eth }(12 \mathrm{~W}) \\
n=8\end{array}$ \\
\hline $\begin{array}{l}\mathrm{BW} \\
(\mathrm{g})\end{array}$ & $189.63 \pm 7.46$ & $\underset{* * *}{166.75 \pm 1.49}$ & $\begin{array}{c}178.38 \pm 3.42 \\
* * \text { \#\#\# }\end{array}$ \\
\hline TNF- $\alpha(\mathbf{p g} / \mathbf{m L})$ & $3.31 \pm 0.80$ & $\underset{* * *}{15.75 \pm 1.00}$ & $\begin{array}{c}5.10 \pm 0.99 \\
* *, \# \# \#\end{array}$ \\
\hline $\begin{array}{c}\text { VEGF } \\
(\mathbf{n g} / \mathbf{m L})\end{array}$ & $55.88 \pm 3.40$ & $\begin{array}{c}47.00 \pm 4.40 \\
* * *\end{array}$ & $\begin{array}{c}51.25 \pm 2.50 \\
* *, \#\end{array}$ \\
\hline $\begin{array}{c}\text { caspase-3 } \\
\text { (U/mg tissue weight) }\end{array}$ & $3.90 \pm 0.70$ & $5.88 \pm \underset{* *}{ \pm 0} 0.80$ & $\begin{array}{c}4.88 \pm 0.80 \\
*, \#\end{array}$ \\
\hline $\begin{array}{c}\text { Serum urea } \\
(\mathbf{m g} / \mathbf{d l})\end{array}$ & $14.25 \pm 1.40$ & $\begin{array}{c}22.13 \pm 2.60 \\
* * *\end{array}$ & $\begin{array}{c}16.75 \pm 2.10 \\
* \text {,\#\#\# }\end{array}$ \\
\hline $\begin{array}{l}\text { Serum creatinine } \\
(\mathbf{m g} / \mathbf{d l})\end{array}$ & $0.47 \pm 0.05$ & $\begin{array}{c}0.57 \pm 0.02 \\
* * *\end{array}$ & $\begin{array}{l}0.52 \pm 0.02 \\
*, \# \#\end{array}$ \\
\hline
\end{tabular}

$* \mathrm{P}<0.05, * * \mathrm{P}<0.01, * * * \mathrm{P}<0.001$, as compared to control group. \# $\mathrm{P}<0.05$, \#\# $\mathrm{P}<0.01$ and \#\#\# $\mathrm{P}<0.001$ as compared to Eth group at twelve weeks. $\mathrm{BW}=$ body weight, $\mathrm{Et}=$ ethanol, Mel+ Eth= melatonin + ethanol, $\mathrm{VEGF}=\mathrm{vascular}$ endothelial growth factor
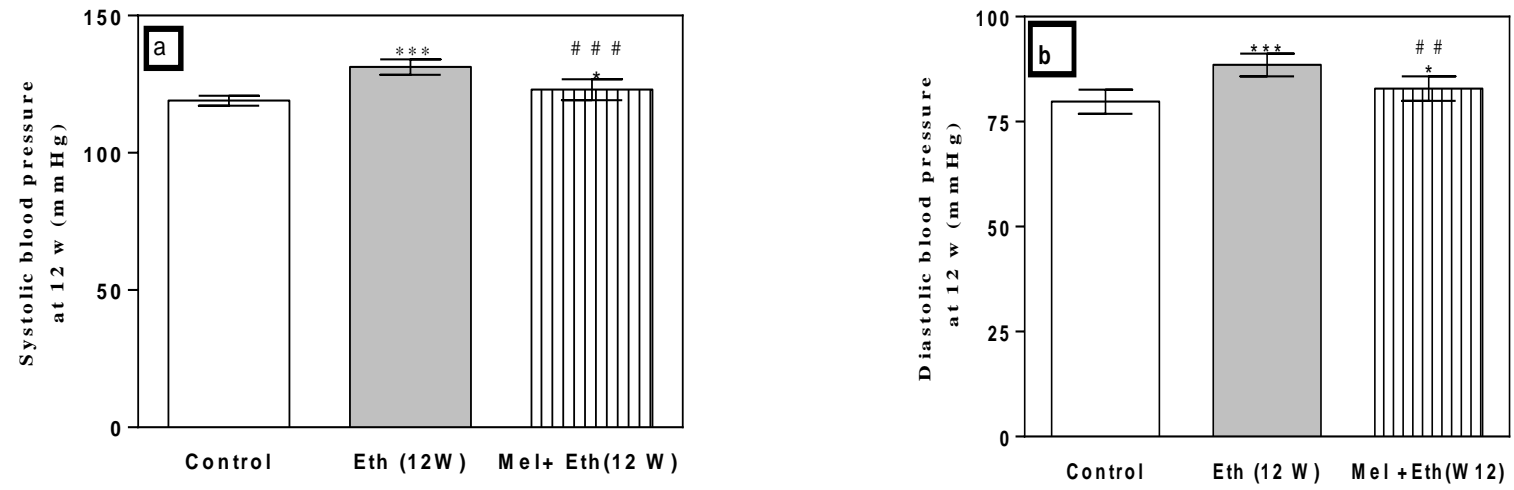

Figure (2), a: mean systolic blood pressure b: mean diastolic blood pressure in the studied groups at twelve weeks. *: $\mathrm{P}<0.05$ and $* * *$ : $\mathrm{P}<0.001$ as compared to control group. \#\#: $\mathrm{P}<0.01$ and \#\#\#: $\mathrm{P}<0.001$ as compared to Eth group. 


\section{Histological changes:}

\section{Control group: (Fig.3a)}

The renal cortex revealed the renal corpuscle includes the glomerulus, Bowman's capsule and the vascular pole. The glomerulus was formed of collection of convoluted capillary blood vessels. Bowman's capsule deeply invaginated by the glomerulus. It was lined by a simple squamous epithelium on its outer wall.

The proximal tubules were lined with cuboidal epithelium with a high brush border. Cell borders were barely visible. The cytoplasm deeply stained and frequently appeared granular, turbid and diffuse. The distal tubules diameters were considerably smaller than those of proximal tubules. There was no brush border.

\section{Ethanol treated for six weeks (Fig.3b) and for} twelve weeks (Fig.3c):

Following ethanol treatment for six weeks dilatation, congestion and thick wall peritubular vessels was seen. Renal corpuscles with dilated bowman's space were obvious. Dilated tubules lined by thinner epithelium with degenerated cells at some areas were also noticed.

However, widened capsular space, degeneration and necrosis of renal tubular epithelia were more obvious following twelve weeks ethanol treatment. These damaging changes reflected toxic effects of ethanol with duration of exposure. Atrophic renal corpuscles in some of fields also noticed.

\section{Melatonin+ ethanol treated group for six weeks}

(Fig.3d) and for twelve weeks (Fig.3e):

The co-administration of melatonin with ethanol for six and twelve weeks ameliorated the toxic changes of ethanol. Dilatation, congestion and thick wall peritubular vessels were less marked. Renal corpuscles were more or less healthy. These findings reflected the protective effects of melatonin on ethanol toxicity.

\section{DISCUSSION}

It is known that alcohol dependence and alcohol abuse causes substantial morbidity and mortality (29). Alcohol consumption has deleterious effects on many vital organs including the kidney (30).

In this work, suppression effects of ethanol on the body weight coincide with (31) who demonstrated a reduction in the body weight of the ethanol treated rats which may be adduced to malnutrition resulting from reduced absorption of nutrients from the intestine. Chronic alcohol consumption provokes greater energy expenditure for that, it was associated with body weight $\operatorname{loss}(3,32)$. Melatonin+ ethanol treated group showed restoration in the body weight that is consistent with the result of (33) who demonstrated that, melatonin promotes food intake in rats by decreasing in the food transit time which lead to empty gastrointestinal tract (GIT) more rapidly and trigger an increase in food intake. Also Sokolovic et al. (34) showed that melatonin administration to irradiated irritable rats caused an increased body weight which was attributed to melatonin mediated anti-stress effect. 

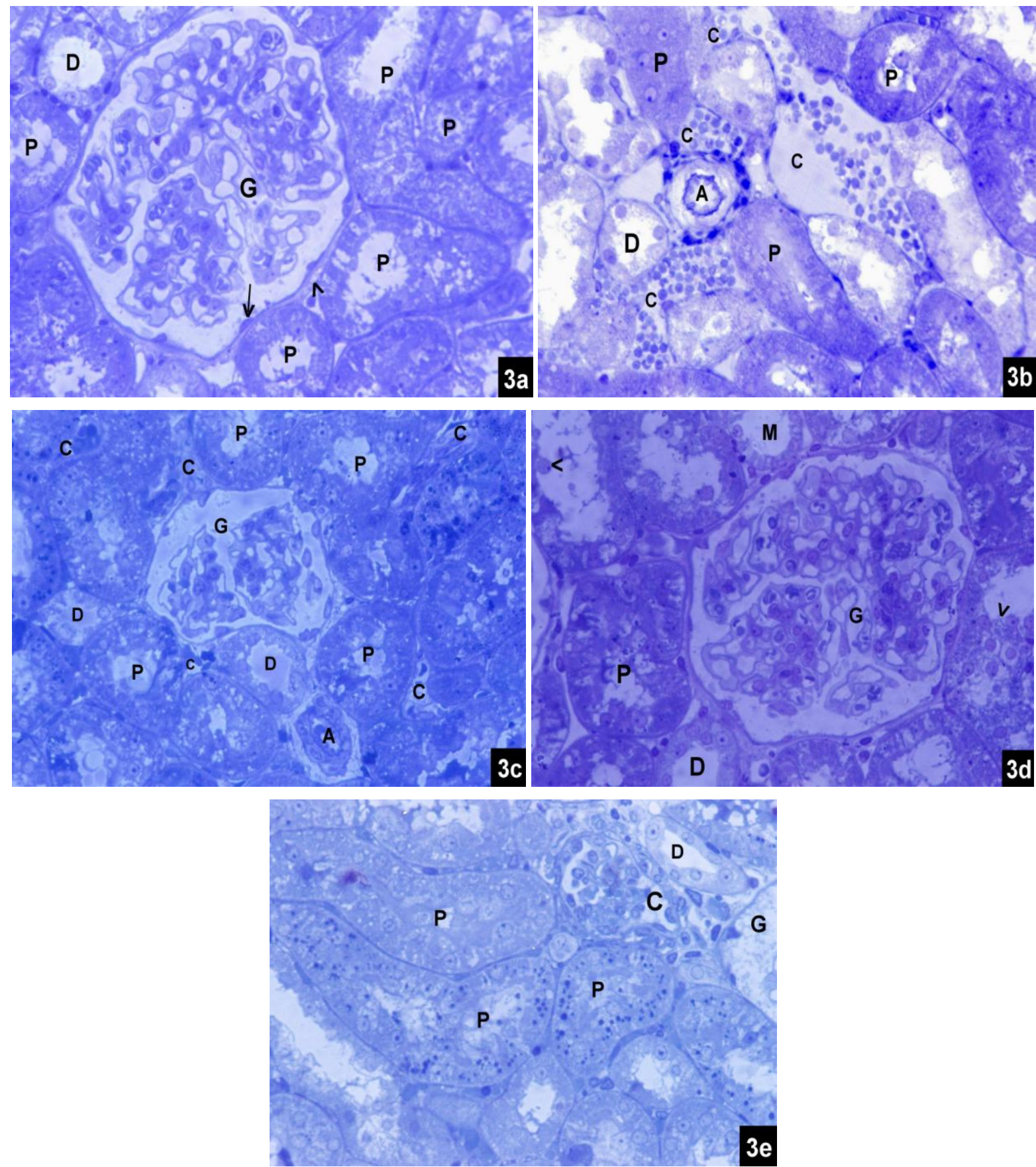

Fig. (3) Histopathological examination of kidney tissues, a) shows: glomerulus (G) lined by a simple squamous epithelium on its outer wall (arrow head) and specialized epithelial podocytes (arrow) on its glomerular wall, proximal convoluted tubules (P) and distal convoluted tubules (D) of control albino rat kidney, (b) shows: proximal convoluted tubules (P), distal convoluted tubules (D) with destruction of its epithelial lining at some areas, thick wall arteriole (A) and congested capillaries with blood (C) in ethanol treated rats for six weeks, (c) shows: atrophic glomerulus $(\mathrm{G})$, proximal convoluted tubules (P), distal convoluted tubules (D) with destruction of its epithelial lining at some areas, thick wall arteriole (A) and congested capillaries with blood clots (C) in ethanol treated rats for twelve weeks, (d) shows: glomerulus (G) lined by a simple squamous epithelium on its outer wall and specialized epithelial podocytes on its its glomerular wall, proximal convoluted tubules (P), distal convoluted tubules (D) and macula densa $(\mathrm{M})$ of melatonin+ ethanol treated group rats for six weeks and (e) shows: part of glomerulus $(\mathrm{G})$, proximal convoluted tubules $(\mathrm{P})$ with their epithelial lining rich in lysosomes, distal convoluted tubules (D) and congested blood capillaries (C) of melatonin+ ethanol treated group for twelve weeks. (Toludine blue X 400) 
The increment of both SBP \& DBP in ethanol treated rats at six and twelve weeks in this study are in agreement with (35) who found that long term ethanol treatment induced the development of pro-inflammatory and pro-atherosclerotic processes, with an increase in blood pressure, suggesting a potential direct implication of ethanol itself in induction of hypertension via inflammation processes.

Overall, the results of this study ethanol treatment for twelve weeks lead to significant increment of urea and creatinine concentration in serum are in lines with the observations of (36, 37) who found significant elevation in blood urea and creatinine levels after twelve weeks of ethanol exposure which indicate initiation of kidney damage, disruption in the structure and function of the kidneys.

It is widely accepted that ethanol consumption causes markedly increase in the serum TNF- $\alpha$ level after six and twelve weeks that in accord with finding of $(38,39,40)$ Who demonstrated that ethanol feeding resulted in increased TNF- $\alpha$. It triggers release of mitochondrial cytochrome $\mathrm{C}$, sequentially activating caspases- 9 and -3 , and resulting in DNA fragmentation and cell death (41).

In patients with hypertension there was an increased production of TNF- $\alpha$ and IL-6, which might play an important role in the initiation and progression of hypertension by a variety of mechanisms such as contraction of vessels, leading to thickening of vascular wall, and proliferation of endothelial cells and smooth muscle cells (42) TNF- $\alpha$ has a role in the pathogenesis of acute and chronic renal disease (43).
Furthermore, it is accepted that the significant increase in TNF- $\alpha$ from six weeks in ethanol treated group may be contributed to increase the blood pressure then this increment lead to risk of renal damage as evident by the marked increase in urea and creatinine concentration in serum of ethanol treated group for twelve weeks. This finding was in agreement with Parekh and Klag (2) who found that Chronic alcohol consumption has been linked with hypertension and therefore indirectly with chronic kidney disease.

It seems probable that the observed, significant increased in renal caspase-3 activity with ethanol treatment for twelve weeks in the present work has a role in the pathogenesis of the renal damage this agrees with study of (44) who revealed that acute and chronic ethanol treatment resulted in significant increases of the hepatocyte apoptosis. Increment of caspase-3 with ethanol consumption may be due to mitochondrial damage, which induces a signaling cascade that activates downstream apoptosis mediators, such as caspase-3, and promotes chromatin degradation, decreases oxygen consumption and ATP production, which can ultimately lead to the initiation of apoptosis (29). Hypertensive renal injury was associated with evidence of activation of the apoptotic pathway (increased activation of caspase-3) (45).Apoptotic death of renal endothelial cells could conceivably lead to a decline in GFR by causing changes in renal vascular tone or by exposing procoagulant subendothelial surfaces(46).

Taking into account that, the marked decrease in serum VEGF level in ethanol treated rats after twelve weeks is in consistent with (47) who 
reported that a decrease in VEGF induced by ethanol in rats' vascular wall. This decrement of VEGF could be due to decreased expression of VEGF receptors and their phosphorylation with ethanol exposure (48). In rodent and human kidneys, VEGF mRNA and/or protein were detected predominantly in glomerular podocytes, distal tubules, and collecting ducts, and to a lesser extent in some proximal tubules (49).In addition, experimental nephron reduction resulted in early peritubular and glomerular endothelial cell proliferation followed by a progressive loss of peritubular and glomerular capillaries, which associated with a decreased VEGF staining in tubules and glomerular podocytes (50).

Moreover, the structural injury as atrophic renal corpuscles, dilatation and congestion of the peritubular vessels and a few foamy-appearing tubules recorded by the histopathological study in this work in the ethanol group that coincides with $(30,51,52)$.

In the present study, supplementation with melatonin showed decrease in the arterial blood pressure in melatonin+ ethanol treated group for six and twelve weeks which can be attributed to, the anti-inflammatory, anti apoptotic and angiogenic properties of melatonin. This observation was confirmed by Nava et al.(53) who showed that in spontaneously hypertensive rats, blood pressure decreased after six weeks of melatonin treatment, which was associated with a reduction of interstitial renal tissue inflammation, decreased oxidative stress and attenuation of expression of NF- $\mathrm{KB}$ in the kidney.

Adewole et al.(23), found that the results of the control and melatonin groups were similar on kidney function parameters and morphology so we exclude the administration of melatonin as a separate control group.

It is important to highlight in this work that the rats in melatonin + ethanol group for twelve weeks which received melatonin decreased significantly serum urea and creatinine levels and preserved more or less the normal morphology of the kidney as compared to the control group. This study is in line with Altintas et al.(54) who found that melatonin significantly diminished serum levels of urea, creatinine and improve the histopathological changes induced by acetylsalicylic acid on kidney.

In the current study, treatment with melatonin significantly decreased serum level of TNF- $\alpha$ in melatonin + ethanol groups that is in consistent with (55). They indicated that melatonin administration lowered the expression of TNF- $\alpha$ and IL-1 $\beta$ in hepatic ischemia/reperfusion injury. In addition, melatonin may be exert its antiinflammatory effects through the inhibition of the activated NF- $\mathrm{KB}$, limitation of excessive production of leukotrienes and other inflammatory mediators such as cytokines, chemokines, and adhesion molecules $(56,57)$. Melatonin protects rats from damage to proximal tubular mitochondria by attenuating oxidative stress and inflammation (58). It has been shown to ameliorate inflammation by blocking transcriptional factors and TNF- $\alpha(59)$.

Importantly, the major findings presented in this work demonstrate that melatonin reduced caspase-3 concentration with consequent reduction of apoptotic and necrotic cell death in the kidney. This results is in accordance with the other studies that confirmed melatonin decreased the release of 
cytochrome $\mathrm{c}$ into the cytoplasm, thus decreasing the activation of caspase- 3 in a rat model of obesity and hepatic steatosis(60). It inhibits caspase-3 activation and prevents apoptotic and necrotic cell death in the kidney (61). Melatonin induced angiogenesis via upregulation of VEGF (62).It brings about significant proangiogenic activity by increasing VEGF expression (63).The ability of melatonin to enhance angiogenesis has been elucidated in gastrointestinal mucosa (64) and during bone repair (65).

Conclusion: The present study clearly demonstrated the renoprotective effects of melatonin in a model of chronic ethanol consumption induced renal damage in adult male rats which could be due to its anti-inflammatory, anti-apoptotic and its angiogenic properties. Also, it may have therapeutic benefits in treatment of hypertension.

\section{Acknowledgments}

The author wish to thank Dr. Ashraf H. Abd ElHakem, Professor in Anatomy Department for his kind help in the histological assessments.

\section{REFERENCES}

1. Das SK and Vasudevan DM: Modulation of lecithin activity by vitamin-B complex to treat on ethanol induced oxidative stress in liver. Ind J Exp Biol. 44: 791-801, 2006.

2. Parekh RS and Klag MJ. Alcohol: Role in the development of hypertension and endstage renal disease. Curr Opin Nephrol Hypertens. 10:385-390, 2001.

3. Barrero MJ, Ojeda ML, Díaz Castro J, Nogales F, Murillo ML and Carreras O: The effects of ethanol upon hydric balance and arterial pressure in rats: folic acid as a possible hypotensor. Life Sci. 27:337-42, 2012.

4. Robin MA, Demeilliers C, Sutton A, Paradis V, Maisonneuve $\mathrm{C}$ and Dubois $\mathrm{S}$, Poirel O, Lettéron P, Pessayre D, Fromenty

B: Alcohol increases tumor necrosis factor alpha and decreases nuclear factor-kappab to activate hepatic apoptosis in genetically obese mice. Hepatology.42: 1280-90, 2005.

5. Jarvelainen HA, Fang C, IngelmanSundberg $M$ and Lindros KO: Effect of chronic coadministration of endotoxin and ethanol on rat liver pathology and proinflammatory and anti-inflammatory cytokines. Hepatology 29: 1503-1510, 1999.

6. Carrero J, Park S, Axelsson J, Lindholm B and Stenvinkel P: Cytokines, atherogenesis and hypercatabolism in chronic kidney disease: a dreadful triad. Semin Dialys. 22(4): 381-386, 2009.

7. Ronis MJ, Korourian S, Blackburn ML, Badeaux J and Badger TM: The role of ethanol metabolism in development of alcoholic steatohepatitis in the rat. Alcohol. 44: 157-69, 2010.

8. Zhang RH, Gao JY, Guo HT, Scott GI, Eason AR, Wang XM and Ren J: Inhibition of CYP2E1 attenuates chronic alcohol intakeinduced myocardial contractile dysfunction and apoptosis. Biochim Biophys Acta.1832: 128-41, 2013.

9. Yamamoto S, Watabe K, Araki H, Kamada Y, Kato M, Kizu T, Kiso S, Tsutsui S, Tsujii M, Kihara S, Funahashi T, Shimomura I, Hayashi N and Takehara T: Protective role of adiponectin against ethanol-induced gastric 
injury in mice. Am J Physiol Gastrointest Liver Physiol. 15: 773-780, 2012.

10. Boyadjieva NI and Sarkar DK: Microglia play a role in ethanol-induced oxidative stress and apoptosis in developing hypothalamic neurons. Alcohol Clin Exp Res. 37: 252-62, 2013.

11. Sinanoglu O, Sezgin G, Ozturk G, Tuncdemir M, Guney S, Aksungar FB, Yener N: Melatonin with 1,25-dihydroxy vitamin

D3 protects against apoptotic ischemiareperfusion injury in the rat kidney. Ren Fail. 34(8):1021-6, 2012.

12. Singh A, Kaushal $\mathbf{V}$ and Megyesi JK: Cloning and expression of rat caspase- 6 and its localization in renal ischemia/reperfusion injury. Kidney Int. 62:106-115, 2002.

13. Ceccanti M, Mancinelli R, Tirassa $\mathbf{P}$, Laviola G, Rossi S, Romeo M and Fiore M: Early exposure to ethanol or red wine and long-lasting effects in aged mice. A study on nerve growth factor, brain-derived neurotrophic factor, hepatocyte growth factor, and vascular endothelial growth factor. Neurobiol Aging. 33:359-67, 2012.

14. Nakagawa T, Sato W, Kosugi $T$ and Johnson RJ: Uncoupling of VEGF with endothelial NO as a potential mechanism for abnormal angiogenesis in the diabetic nephropathy. $J$ Diabetes Res. 9. doi: 10.1155/2013/184539, 2013.

15. Kanellis J, Fraser $\mathbf{S}$, Katerelos $M$ and Power DA: Vascular endothelial growth factor is a survival factor for renal tubular epithelial cells. Am J Physiol Renal Physiol.278: F905-F915, 2000.

16. Masuda Y, Shimizu A, Mori T, Ishiwata T, Kitamura H, Ohashi R, Ishizaki M, Asano G, Sugisaki Y and Yamanaka N: Vascular endothelial growth factor enhances glomerular capillary repair and accelerates resolution of experimentally induced glomerulonephritis. Am J Pathol. 159: 599-608, 2001.

17. Cekmez F, Cetinkaya M, Tayman C, Canpolat FE, Kafa IM, Uysal S, Tunc T and Sarıcı SÜ: Evaluation of melatonin and prostaglandin E1 combination on necrotizing enterocolitis model in neonatal rats. Regul Pept. 10: 121-25, 2013.

18. Tahan V, Atug O, Akin H, Eren F, Tahan G, Tarcin O, Uzun H, Ozdogan O, Tarcin O, Imeryuz N, Ozguner F, Celikel C, Avsar E and Tozun N: Melatonin ameliorates methionine- and choline-deficient diet-induced non- alcoholic steatohepatitis in rats. $J$ Pineal Res. 46: 401-7, 2009.

19. Nasri H, Tavakoli M, Ahmadi A, Baradaran A, Nematbakhsh m, RafieianKopaei M. ameliorative effect of melatonin against contrast media induced renal tubular cell injury. Pak J Med Sci. 30: 261-5, 2014.

20. Kalra S, Agrawal S and Sahay M: The reno-pineal axis: A novel role for melatonin. Indian $J$ of Endocrinology and Metabolism. 16: 192-194, 2012.

21. Kapić D, Mornjaković Z, Ćosović E, Šahinović M. A histological study of the effect of exogenous melatonin on gentamicin induced structural alterations of proximal tubules in rats. Bosn J Basic Med Sci. 2014 Feb;14(1):30-4. 
22. Alimi H, Bouonic Z, Ferianic A, Hfaeidhc N, Saklyb $M$ and Rhoumab KB: Opuntia ficus indica $f$. inermis fruit juice alleviates ethanol-induced kidney injury in rats. Asian $J$. of Biomedical and Pharmaceutical Sciences. 3: 15-21, 2013.

23. Adewole SO, Salako AA, Doherty OW and Naicker T: Effect of Melatonin on Carbon Tetrachloride-Induced Kidney Injury in Wistar Rats. African J. of Biomedical Research.10:153-64, 2007.

24. Ucar F, Taslipinar MY, Alp BF, Aydin I, Aydin FN, Agilli M, Toygar M, Ozkan E, Macit E, Oztosun M, Cayci T, Ozcan A: The effects of $\mathrm{N}$ - acetylcystine and ozone therapy on oxidative stress and inflammation in acetaminophen - induced nephrotoxicity model. Ren Fail.35(5):640-7,2013.

25. Margoni A, Perrea DN, Vlachos I, Prokopaki G, Pantopoulou A, Fotis L, Kostaki M, Papavassiliou AG: Serum leptin, adiponectin and tumor necrosis factor- $\alpha$ in hyperlipidemic rats with or without concomitant diabetes mellitus. Mol Med. JanFeb;17(1-2):36-40,2011.

26. Pawlikowski M, Pisarek H, Fryczak J, Stępień H:

Effects of nitric oxide synthase inhibition on di ethylstilbestrol-

induced hyperprolactinaemia and pituitarytum ourigenesis in rats. Endokrynol Pol.63(2):1158, 2012.

27. Baraka A and Ghoneim M: Role of heat shock protein in renal ischemic reperfusion injury in rats. Afr. J. Pharm. Pharmacol Vol. 5(18), pp. 2050-2055, 2011
28. Gupta PD: Ultrastructural study on semithin section. Science tools. 30: 6-7, 1983.

29. Ge N, Liang H, Liu Y, Ma AG, Han L: Protective effect of Aplysin on hepatic injury in ethanol-treated rats. Food Chem Toxicol. 62: 361-72, 2013.

30. Das SK, Varadhan S, Dhanya L, Mukherjee $S$ and Vasudevan DM: Effects of chronic ethanol exposure on renal function tests and oxidative stress in kidney. Indian $J$ Clin Biochem. 23: 341-4, 2008.

31. Macdonald IO, Olusola OJ and Osaigbovo UA: Effects of chronic ethanol administration on body weight, reduced glutathione (GSH), malondialdehyde (MDA) levels and glutathione-s-transferase activity (GST) in Rats. New York Sci J. 3: 39-47, 2010.

32. Al-Gehani SA: Toxicological influence of ethanol and biochemical changes in rats exposed to cadmium. Merit Res J Environ Sci Toxicol. 1: 51-59, 2013.

33. Angers K, Haddad N, Selmaoui $B$ and Thibault L: Effect of melatonin on total food intake and macronutrient choice in rats. Physiol Behav. 80: 9-18, 2003.

34. Sokolovic D, Djordjevic B, Kocic G, Babovic P, Ristic G, Stanojkovic Z, Sokolovic DM, Veljkovic A, Jankovic A and Radovanovic Z: The effect of melatonin on body mass and behaviour of rats during an exposure to microwave radiation from mobile phone. Bratisl Lek Listy. 113: 265-9, 2012.

35. Shirpoor A, Salami S, Khadem-Ansari MH, Heshmatian B and Ilkhanizadeh B: Longterm ethanol consumption initiates atherosclerosis in rat aorta through inflammatory stress and endothelial 
dysfunction. Vascul Pharmacol. 57: 72-7, 2012.

36. Das SK, Dhanya L, Varadhan S, Mukherjee $S$ and Vasudevan DM: Effects of chronic ethanol consumption in blood: A time dependent study on rat. Indian J Clin Biochem. 24: 301-6, 2009.

37. White SL, Polkinghorne KR, Cass A, Shaw JE, Atkins RC and Chadban SJ: Alcohol consumption and 5-year onset of chronic kidney disease: The AusDiab study. Nephrol Dial Transplant. 24: 2464-72, 2009.

38. Jayaraman J, Jesudoss VA, Menon VP and Namasivayam N: Anti-inflammatory role of naringenin in rats with ethanol induced liver injury. Toxicol Mech Methods.22: 568-76, 2012.

39. Du Y, Zhao W, Lu L, Zheng J, Hu X, Yu Z and Zhu L: Study on the antiulcer effects of Veronicastrum axillare on gastric ulcer in rats induced by ethanol based on tumor necrosis factor- $\alpha$ (TNF- $\alpha$ ) and endothelin-1 (ET-1). Asian Pac J Trop Biomed. 3: 925-30, 2013.

40. Pourbakhsh H, Taghiabadi E, Abnous K, Hariri AT, Hosseini SM, Hosseinzadeh H. Effect of Nigella sativa fixed oil on ethanol toxicity in rats.Iran $\mathrm{J}$ Basic Med Sci. 2014 Dec;17(12):1020-31.

41. Siegel RM: Caspases at the crossroads of immune-cell life and death. Nat Rev Immunol. 6: 308-17, 2006.

42. Bautista LE, Vera LM, Arenas IA and Gamarra G: Independent association between inflammatory markers (C-reactive protein,interleukin-6, and TNF-alpha) and essential hypertension. J Hum Hypertens.19: 149-154, 2005.
43. Vielhauer V and Mayadas TN: Functions of TNF and its receptors in renal disease: distinct roles in inflammatory tissue injury and immune regulation. Semin Nephrol. 27: 286308, 2007.

44. Lu Y, Wu D, Wang X, Ward SC and Cederbaum AI: Chronic alcohol-induced liver injury and oxidant stress are decreased in cytochrome P4502E1 knockout mice and restored in humanized cytochrome P4502E1 knock-in mice. Free Radic Biol Med. 15: 1406-16, 2010.

45. Lazaro A, Gallego-Delgado J, Justo $\mathbf{P}$, Esteban V, Osende J, Mezzano S, Ortiz A and Egido J. Long-term blood pressure control prevents oxidative renal injury. Antioxid Redox Signal. 7: 1285-93, 2005.

46. Guo R, Wang Y, Minto AW, Quigg RJ and Cunningham PN: Acute renal failure in endotoxemia is dependent on caspase activation. J Am Soc Nephrol 15: 3093-3102, 2004.

47. Shirpoor A, Norouzi L, Khadem Ansari MH, Ilkhanizadeh B and Gharaaghaji R: Vasoprotective effect of vitamin E: rescue of ethanol-induced atherosclerosis and inflammatory stress in rat vascular wall. Int Immunopharmacol. 16: 498-504, 2013.

48. Radek KA, Kovacs EJ, Gallo RL and DiPietro LA: Acute ethanol exposure disrupts VEGF receptor cell signaling in endothelial cells. Am J Physiol Heart Circ Physiol. 295: 174-84, 2008.

49. Kang DH, Anderson S and Kim YG: Impaired angiogenesis in the aging kidney: Vascular endothelial growth factor and 
thrombospondin-1 in renal disease. $A m \quad J$ Kidney Dis 37: 601-611, 2001.

50. Kelly DJ, Hepper C and Wu LL: Vascular endothelial growth factor expression and glomerular endothelial cell loss in the remnant kidney model. Nephrol Dial Transplant 18: 1286-1292, 2003.

51. Shanmugam KR, Ramakrishna CH, Mallikarjuna $\mathrm{K}$ and Reddy KS: Protective effect of ginger against alcoholinduced renal damage and antioxidant enzymes in male albino rats. Indian $J$ Exp Biol. 48: 143-9, 2010.

52. Sonmez MF, Narin F, Akkuş $D$ and Türkmen

AB:

Melatonin and vitamin $\mathrm{C}$ ameliorate alcoholin duced oxidative stress and eNOS expression in rat kidney. Ren Fail. 34: 480-6, 2012.

53. Nava M, Quiroz Y and Vaziri N: Melatonin reduces renal interstitial inflammation and improves hypertension in spontaneously hypertensive rats. Am J Physiol Renal Physiol. 284: F447-54, 2003.

54. Altintas R, Polat A, Parlakpinar H, Vardi N, Beytur A, Oguz F, Sagir M, Yildiz A and Duran Z: The effect of melatonin on acetylsalicylic acid-induced kidney and testis damage. Hum Exp Toxicol. 33: 383-95, 2014.

55. Kireev RA, Cuesta S, Ibarrola C, Bela T, Moreno Gonzalez E and Vara E: Agerelated differences in hepatic ischemia/reperfusion: gene activation, liver injury, and protective effect of melatonin. $J$ Surg Res.178: 922-34, 2012.

56. Mauriz JL, Collado PS, Veneroso C, Reiter RJ and González-Gallego J: A review of the molecular aspects of melatonin's anti- inflammatory actions: recent insights and new perspectives. J Pineal Res. 54: 1-14, 2012.

57. Permpoonputtana $\mathbf{K}$ and Govitrapong $\mathbf{P}$ : The anti-inflammatory effect of melatonin on methamphetamine-induced proinflammatory mediators in human neuroblastoma dopamine SH-SY5Y cell lines. Neurotox Res.23: 189-99, 2013.

58. Ramamoorthy $\mathbf{H}$, Abraham $P$ and Isaac B: preclinical efficacy of melatonin in the amelioration of tenofovir nephrotoxicity by the attenuation of oxidative stress, nitrosative stress and inflammation in rats. $\mathbf{J}$ Basic Clin Physiol Pharmacol. Jan 27:1-13, 2014.

59. Ronald RW: Melatonin in the promotion of Health, $2^{\text {nd }}$ edition, CRC Press, USA, 2011.

60. Kireev R, Bitoun S, Cuesta S, Tejerina A, Ibarrola C, Moreno E, Vara E and Tresguerres JA: Melatonin treatment protects liver of Zucker rats after ischemia/reperfusion by diminishing oxidative stress and apoptosis. Eur J Pharmacol. 15: 185-93, 2013.

61. Kunduzova OR, Escourrou G, Seguelas MH, Delagrange P, De La Farge F, Cambon C and Parini A. Prevention of apoptotic and necrotic cell death, caspase-3 activation, and renal dysfunction by melatonin after ischemia/reperfusion. FASEB $J$ May;17(8): 872-4. 2003.

62. Ganguly K, Sharma AV, Reiter RJ and Swarnakar

S:

Melatonin promotes angiogenesis during prote ction and healing of indomethacin induced gastric ulcer: role of matrix metaloproteinase2. J Pineal Res. 49: 130-40, 2010. 
63. Pugazhenthi K, Kapoor $M$ and Clarkson AN: Melatonin accelerates the process of wound repair in full-thickness incisional wounds. J Pineal Res. 44: 387-96, 2008.

64. Palileo C and Kaunitz JD: Gastrointestinal defense mechanisms. Curr Opin Gastroenterol. 27: 543-48, 2011.

65. Ramírez-Fernández MP，Calvo-Guirado JL, de-Val JE, Delgado-Ruiz RA, Negri B, Pardo-Zamora G, Peñarrocha D, Barona C, Granero JM and Alcaraz-Baños M: Melatonin promotes angiogenesis during repair of bone defects: a radiological and histomorphometric study in rabbit tibiae. Clin Oral Investig. 17: 147-58, 2013. 
دور الميلاتونين في تعديل ضغط الام الشريانى والتليف الكلوى الناجم عن استهلاك الإيثانول فى ذكورالفئران البالغة

$$
\begin{aligned}
& \text { إبتهال أنور عبد العزيز } \\
& \text { قسم الفسيولوجىـ كلية الطبـ جامعة أسيوط }
\end{aligned}
$$

مقدمة: تناول الإيثانول يؤدي إلي ارتفاع ضغط الدم والعديد من صور الخلل الكلوي الوظيفي ـ يعتبر الميلاتونين من مضادات الأكسدة وله تأثثر مضاد للالتهابات.

الههف من الاراسة: تهدف هذه الرسالة للكثف عن دور الميلاتونين على ضغط الدم الثرياني وآثاره الوقائية المحتملة ضد الخلل الكلوي الوظيفي الناجم عن تناول الايثانول في ذكور الفئران البالغة مع محاولة تفسير هذا التأثير الوقائي باستخدام أساليب بيوكيميائية وهستولوجية لتوضيح هذا التأثنير . لإسي الأساليب: أستخدمت في هذه الدر اسة ثمانية وأربعون من الفئر ان البيضاء قسمت إلى ثنلاث مجموعات. المجمو عة الأولي: هي المجمو عة الضابطة ، و المجمو عة الثنانية: هي مجمو عة الإيثانول حيث أعطيت حيو انات هذه المجمو عة 10 مل / كغم من وزن الفأر

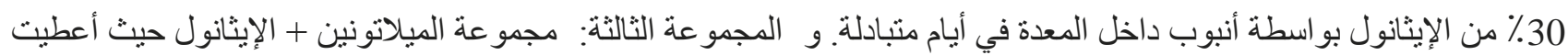
حيو انات هذه المجموعة الايثانول بنفس الحر عة السابقة مع جر عة 5 ملغ / كغ من المبلاتونين حقن تحت الجلد في أيام منبادلة. تم التضحية بنصف الحيو انات من كل مجمو عة بعد ستة اسابيع و الباقى بعد اثني عشر أسبو عا. النتائج: الحيو انات التي أعطيث الايثانول لمدة 6 ،12 أسبوع كان هناك انخفاض ملحوظ في الوزن الجسم ، إرتفاع معنوي في ضغط

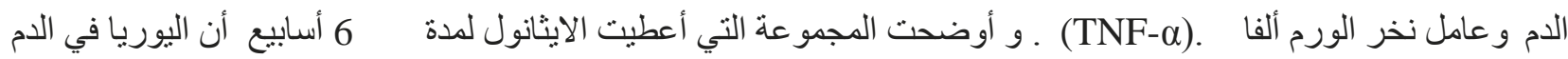
و الكرياتينين، و عامل النمو البطاني الوعائي (VEGF) ، و الكاسباس الكلوى-3 لم يتغير تغير ا معنويا ، أما التي أعطيت الايثانول لمدة 12 فقد لوحظ إرتفاع هذه المعايير إلى إرتفاعا معنويا باستثناء هستولوجية مرضية في الحيو انات التي أعطيت الايثانول لمدة 6 ، 12 أسبوع بينما تحسنت هذه التغير ات المرضية في المجمو عة التي تناولت الميلاتونين مع الإثانول. التوصيات: خلصت الدراسة إلى ان الميلاتونين له دور وقائي في ارتفاع ضغط الدم الثريانى و ضد التلف الناتج عن تناول الايثانول في الكلى. 